\begin{tabular}{|l|l|l||}
\hline \multicolumn{2}{|c|}{ PublisherInfo } \\
\hline \hline PublisherName & $:$ & BioMed Central \\
\hline \hline PublisherLocation & $:$ & London \\
\hline \hline PublisherImprintName & $:$ & BioMed Central \\
\hline \hline
\end{tabular}

\title{
IL-1a and arthritis
}

\begin{tabular}{|l|l|l||}
\hline \multicolumn{2}{|c|}{ ArticleInfo } \\
\hline \hline ArticleID & $:$ & 73 \\
\hline \hline ArticleDOI & $:$ & $10.1186 /$ ar-2001-70102 \\
\hline \hline ArticleCitationID & $:$ & 70102 \\
\hline \hline ArticleSequenceNumber & $:$ & 30 \\
\hline \hline ArticleCategory & $:$ & Paper Report \\
\hline \hline ArticleFirstPage & $:$ & 1 \\
\hline \hline ArticleLastPage & $:$ & 3 \\
\hline \hline & & RegistrationDate : 2001-7-31 \\
ArticleHistory & $:$ & Received \\
\hline \hline ArticleCopyright & $:$ & Biomed Central Ltd2001-7-9 \\
\hline \hline ArticleGrants & $:$ & \\
\hline \hline ArticleContext & $:$ & 130753311 \\
\hline \hline
\end{tabular}


Aff1 Imperial College School of Medicine, London, UK

\section{Keywords}

Arthritis, IL-1a, macrophage, neutrophil

\section{Context}

Interleukin (IL)-1 has been implicated in the pathogenesis of rheumatoid arthritis (RA) and is thought particularly to play a central role in joint destruction. Elevated levels of IL-1 are present in the synovial fluid, synovial membrane and cartilage-pannus junction of arthritic joints. The relative contributions of IL-1 and tumour necrosis factor (TNF)-a and the roles of T-cell-independent and antigen-specific T-celldependent mechanisms in rheumatoid synovitis are still unclear. The authors investigated the potential direct effect of IL-1a on arthritis in mice transgenic (Tg) for human IL-1a (hIL-1a).

\section{Significant findings}

Overexpression of hIL-1a was detected at both the mRNA and protein levels in a wide variety of tissues, including synoviocytes and bone marrow (BM) macrophages. The hIL-1a secreted by synoviocytes and BM macrophages was shown to be biologically active. Synovial hyperplasia (resulting from accumulation of cells with a macrophage-like morphology), loss of cartilage, bone erosion, fibrin deposits and the formation of pannus-like tissue were revealed in 8-week-old mice. Nearly $80 \%$ of freshly isolated synoviocytes were positive for the F4/80 antigen. The majority of the cells infiltrating below and within the synovium were polymorphonuclear neutrophils (PMNs) and expressed high levels of Gr-1, indicating they were mature, tissue-degrading PMNs. Granulocyte-macrophage colonystimulating factor was found to be twofold to threefold higher in supernatants from synoviocytes and $\mathrm{BM}$ macrophages and in the sera of $\mathrm{Tg}$ mice compared to sera of non-Tg littermates.

\section{Comments}


This study provides insight into the role of IL-1 in arthritis. Although several RA models have implicated lymphocytes in the pathogenesis of inflammatory arthritis, very few a/?T-cell receptor ${ }^{+}$cells,

$\mathrm{B}_{22}{ }^{+}$cells or $\mathrm{CD} 80^{+} / \mathrm{CD} 86^{+}$cells were observed in the joints of the hIL-1a Tg mice studied here. The authors speculate that hIL-1a may modulate synoviocytes towards a tissue-destructive phenotype rather than having an antigen-presenting function, implying the development of inflammatory arthritis in a $\mathrm{T}$ cell-independent manner. The relative contributions of IL-1 and TNF-a in RA are difficult to clarify. Distinguishing between the effects of these two cytokines is especially difficult in Tg mice because TNF mRNA was induced in the hIL-1a Tg mice (stated in discussion, but data not shown) and also IL-1 receptor antagonist modulates disease in TNF-Tg mice. The study of the IL-1a transgene on a TNFdeficient background may be one way to clarify the role of IL-1 in RA. It would be interesting to determine, in this Tg mouse model, which other cytokines could play a role in chronic inflammatory arthritis.

\section{Methods}

Generation of transgenic mice, cell culture, northern blot analysis, immunoprecipitation, SDS-PAGE, ELISA, bioassay, immunohistochemistry, flow cytometry, histological analysis

\section{Additional information}

Keffer J, Probert L, Cazlaris H, Georgopoulos S, Kaslaris E, Kioussis D, Kollias G: Transgenic mice expressing human tumour necrosis factor: a predictive genetic model of arthritis. $E M B O J 1991$, 10:4025-4031 (PubMed abstract).

Probert L, Plows D, Kontogeorgos G, Kollias G: The type I interleukin-1 receptor acts in series with tumor necrosis factor (TNF) to induce arthritis in TNF-transgenic mice. Eur J Immunol 1995, 25:1794-1797 (PubMed abstract).

\section{References}

1. Niki Y, Yamada H, Seki S, Kikuchi T, Takaishi H, Toyama Y, Fujikawa K, Tada N: Macrophageand neutrophil-dominant arthritis in human IL-1a transgenic mice. J Clin Invest. 2001, 107: 1127-1135.

This PDF file was created after publication. 